Klinik Araştırma / Clinical Research

\title{
Erken evre glottik larenks kanserinde radyoterapi sonuçları: Tek merkez deneyimi
}

\author{
Results of radiotherapy in early stage glottic laryngeal carcinoma: A single center experience \\ Deniz Meydan*a, Bilge Gürsela ${ }^{\mathrm{a}}$, Nilgün Şahin ${ }^{\mathrm{b}}$, Nilgün Özbek ${ }^{\mathrm{a}}$ \\ aOndokuz Mayls Üniversitesi Tıp Fakültesi Radyasyon Onkolojisi Anabilim Dall, Samsun, Türkiye

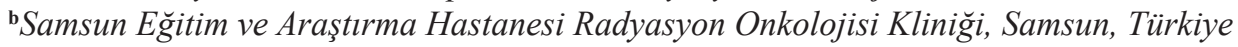

\begin{tabular}{|c|c|}
\hline MAKALE I & GÍLERİ \\
\hline Makale geçı & \\
\hline Geliş tarihi & : 07 / 04 / 2012 \\
\hline Kabul tarihi & : $10 / 04 / 2012$ \\
\hline
\end{tabular}

\author{
* Yazışma Adresi: \\ Deniz Meydan \\ Ondokuz Mayıs Üniversitesi \\ Tıp Fakültesi \\ Radyasyon Onkolojisi Anabilim Dalı \\ Samsun, Türkiye \\ e-posta: admeydan@omu.edu.tr
}

\author{
Anahtar Kelimeler: \\ Glottik kanser \\ Erken evre \\ Radyoterapi \\ Lokal kontrol \\ Sağkalım \\ Prognostik faktörler
}

\section{Keywords:}

Glottic cancer

Early stage

Radiotherapy

Local control

Survival

Prognostic factors

\section{ÖZET}

Erken evre glottik larenks kanseri tanısı ile küratif radyoterapi uygulanmış olgularda geriye dönük olarak tedavi sonuçlarının ve prognostik faktörlerin değerlendirilmesi amaçlandı. 1993-2010 yılları arasında kliniğimizde radyoterapi uygulanan, biyopsi ile histopatolojik olarak kanser tanısı doğrulanmış ve RT öncesi herhangi bir tedavi uygulanmamış erken evre (T1-2N0) glottik larenks kanserli 73 olgu geriye dönük olarak incelendi. Tüm olguların verileri güncellenerek hasta, tümör ve tedaviye ait parametrelerin lokal-bölgesel kontrol ve sağkalım üzerine olan etkileri araştırıldı. Hastaların medyan yaşı 60 (37-83) olup 69'u erkek, 4'ü kadındır. Evrelere göre dağılım; 41'i (\% 56,2) T1a, 8'i (\% 10,9) T1b, 24 'ü $(\% 32,9)$ T2 şeklindedir. Hastalara medyan 66 Gy $(58,5-72)$ eksternal radyoterapi uygulanmıştır. Radyoterapiye bağlı olarak, 1 olguda $(\% 1,4)$ grade $3-4$ erken ve geç larengeal ödem gelişmiş, bu olgu dışında diğer olguların hiçbirinde grade 3-4 erken ve geç toksisite ile karşılaşılmamıştır. Medyan 73 (5-209) aylık takipte toplam 10 (\% 13,7) hastada lokal-bölgesel nüks saptanmış, hiçbir olguda uzak metastaz saptanmamıştır. Hastaların 5 yıllık lokal-bölgesel kontrol, hastalığa özgü sağkalım ve genel sağkalım oranı sırası ile \% 85, \% 92 ve \% 78'dir. İncelenen faktörlerden "tedaviye 5 gün ve daha fazla ara verilmesi” lokal-bölgesel kontrol ve hastalığa özgü sağkalımı anlamlı olarak azaltırken (sırası ile $\mathrm{p}=0,008, \mathrm{p}=0,036$ ), "tedavi öncesi ses kısıklığı süresinin 5 aydan az olmasının" sadece lokal-bölgesel kontrolü anlamlı olarak azalttığı $(\mathrm{p}=0,036)$ saptanmıştır. Sonuç olarak, erken evre glottik larenks kanserinde primer tedavi olarak radyoterapi yüksek lokal kontrol oranlarına sahip etkin bir tedavi şeklidir. Radyoterapiye çeşitli nedenlerden dolayı verilen aralar lokal-bölgesel kontrolü ve hastalığa özgü sağkalımı olumsuz etkileyen prognostik bir faktördür. $\mathrm{Bu}$ nedenle tedavi aralarından mümkün olduğunca kaçınılmalıdır.

J. Exp. Clin. Med., 2012; 29:141-147

\section{ABSTRACT}

Patients with early stage glottic laryngeal cancer treated with curative radiotherapy were aimed to evaluate retrospectively for their treatment results and prognostic factors. In between 1993-2010, early stage (T1-2N0) 73 glottic laryngeal cancer cases which were treated with radiotherapy in our department that histopathological diagnosis of cancer was confirmed by biopsy and without any treatment prior to RT, were retrospectively analyzed. Patient, tumor and treatment parameters of all cases were updated and their effects on the local-regional control and survival were investigated. The median age of patients was 60 (37-83) and 69 patients were male and 4 were female. The distributions of patients according to stages were as follows: $41(56.2 \%)$ T1a, $8(10.9 \%)$ T1b and $24(32.9 \%)$ T2. Median of 66 Gy (58.5-72) of external beam radiotherapy was delivered to patients. In a patient $(1.4 \%)$, grade $3-4$ early and late laryngeal edema depending on radiotherapy was developed. In other patients except from this patient, early and late grade 3-4 toxicity was not observed. During a median 73 months (5-209) follow-up, local recurrence was detected in $10(13.7 \%)$ cases and no distant metastasis was observed. Five year localregional control, disease-specific and overall survival rates were $85 \%, 92 \%$ and $78 \%$, respectively. From the investigated factors, while 5 or more days treatment interruption 
was found to decrease significantly local-regional control and disease-specific survival ( $p=0.008, p=0.036$, respectively), less than 5 months duration of hoarseness was found to decrease significantly only local-regional control $(\mathrm{p}=0.036)$. In conclusion, radiotherapy as primary treatment modality in the early stage laryngeal cancer is an effective form of treatment with high rates of local control. Radiotherapy interruption due to various reasons is a prognostic factor which adversely effects loco-regional control and diseasespecific survival. Therefore, interruptions during the radiotherapy should be avoided as much as possible.

J. Exp. Clin. Med., 2012; 29:141-147

(C) 2012 OMU

\section{Giriş}

Erken evre glottik larenks kanseri, cerrahi veya definitif radyoterapi (RT) ile tedavi edilebilen, her iki tedavi modeli ile de yüksek lokal kontrol oranına sahip, kür sağlanabilen bir hastalıktır (Pelitteri ve ark., 1991; Mendenhall ve ark., 1998). Tedavide amaç kür sağlamak olduğu kadar larenks fonksiyonunu da korumaktır. RT'nin larenks yapı ve fonksiyonunu korumadaki avantajı birçok çalışmada belgelenmiştir ve günümüzde birçok merkezde ilk tercih edilen tedavi seçeneğidir (Mendenhall ve ark., 1988; Johansen ve ark., 1990; Le ve ark., 1997; Warde ve ark., 1998; Mendenhall ve ark., 2001). RT sonrasi 5 y1llı lokal kontrol oranları T1 tümörler için \% 85-94, T2 tümörler için \% 70-80 aralığında değişmektedir (Mendenhall ve ark., 1988; Le ve ark., 1997; Warde ve ark., 1998; Mendenhall ve ark., 2001). Lokal nüks sonrası kurtarıcı cerrahi ile \% 90-100 oranında 5 yıllık lokal kontrol oranları sağlanabilir (Stevenson ve ark., 1992; Rudoltz ve ark., 1993). RT sonrası lokal kontrol oranları yaş, cinsiyet, disfoni süresi, T evresi, kötü histolojik diferansiasyon, ön komissür tutulumu, tedavi öncesi hemoglogin düzeyi, fraksiyon dozu, toplam doz, toplam tedavi süresi gibi çeşitli prognostik faktörlerden etkilenmektedir (Warde ve ark., 1998; Mendenhall ve ark., 2001; Franchin ve ark., 2003; Zouhair ve ark., 2004). Bu çalışmada kliniğimize başvuran erken evre glottik larenks kanseri tanısı almış ve küratif RT uygulanmış olgularda geriye dönük olarak tedavi sonuçlarının ve prognostik faktörlerin değerlendirilmesi amaçlandı.

\section{Gereç ve yöntem}

1993-2010 yılları arasında kliniğimizde RT uygulanan, histopatolojik olarak kanser tanısı doğrulanmış, erken evre (T1-2N0) glottik larenks kanserli 73 olgu geriye dönük olarak incelendi. Olgularda histopatolojik tanı biyopsi ile konmuş olup biyopsi dışında tedavi amaçlı herhangi bir işlem uygulanmamıştır. Tüm olguların, dosya kayıtları incelenerek indirekt laringoskopi, direkt laringoskopi ve bilgisayarlı tomografi bulguları eşliğinde tümörleri 2010 TNM (American Joint Committee on Cancer-AJCC) evreleme sistemine göre yeniden evrelendi ve verileri güncellendi. Olguların tamamı termoplastik baş sabitleyici ile sabitleme sağlandıktan sonra kobalt 60 (Co 60) veya lineer akseleratör (linak) teleterapi cihazı ile haftada 5 gün, günde tek fraksiyon, 200 veya 225 cGy/gün fraksiyon dozunda işınlanmıştır. Tedavi volümünü, T1N0 tümörlerde $(\mathrm{n}=49)$, sınırlarını arkada prevertebral fasya, yukarıda hiyoid kemik altı, aşağıda krikoid kartilaj alt1 ve önde 1-2 cm boşluğun oluşturduğu, esas olarak glottik bölgeyi içeren alan oluşturmuştur. T2N0 tümörlerde $(n=24)$ ise alan T1N0 tümörlere benzer şekilde esas olarak tümörün yayılımına uygun olarak konumlandırılmıştır $(n=10)$. İleri T2N0 olgularda ise ( $\mathrm{n}=14$ ) elektif nodal ışınlama (subdigastrik ve midjuguler nodlar) yapılmıştır. Literatürde lokal-bölgesel kontrol ve sağkalıma etkisi araştırılan cinsiyet, yaş, sigara ve alkol kullanımı, tedavi öncesi ses kısıklığı süresi, tanıda hemoglobin düzeyi, T evresi, ön komissür tutulumu, tümör derecesi, radyoterapi fraksiyon dozu, toplam RT dozu, RT'ye verilen ara, toplam tedavi süresi ve tedavi cihazı gibi hasta, tümör ve tedaviye ait parametrelerin lokal kontrol ve hastalığa özgü sağkalım üzerine olan etkisi incelendi.

İstatistiksel analiz SPSS (Statistical Package for Social Sciences) 15,0 programı ile yapıldı. Tüm hipotezler çift yönlü kuruldu ve $\mathrm{p}<0,05$ anlamlılık sınırı olarak kabul edildi. Lokal-bölgesel kontrol, RT bitiminden ilk lokal veya bölgesel yinelemenin saptandığı veya lokal-bölgesel yineleme yok ise RT bitiminden son kontrol tarihi veya hasta ölüm tarihine; hastalığa özgü ve genel sağ kalım, tanıdan son kontrol veya hasta ölüm tarihine göre hesaplandı. Tüm sağ kalım analizleri Kaplan-Meier yöntemi ile yapıldı ve gruplar arası karşılaştırmalarda log-rank testi kullanıldı.

\section{Bulgular}

Hastaların medyan yaşı 60 (37-83) olup 69'u erkek, 4'ü kadındır. Hastaların tümünde doku tanısı epidermoid karsinom olup evrelere göre dağılım; 41'i (\% 56,2) T1a, 8'i $(\% 10,9)$ T1b, 24’ü (\% 32,9) T2 şeklindedir. Kırkbeş hastaya Co 60 teleterapi cihazı ile 28 hastaya ise linak ile medyan 66 Gy $(58,5-72)$ eksternal RT uygulanmıştır. Fraksiyon dozu 43 (\% 58,9) hastada 200cGy/gün iken, 30’unda (\% 41,1) 225 cGy/gün'dür. Yetmiş üç hastanın 5 'ine haftada altı gün olacak şekilde 1lımlı akselere RT uygulanmıştır (Tablo 1).

Tüm olguların medyan takip süresi 73 ay olup 5 ila 209 ay arasında değişmektedir. Olguların 60'1 yaşarken 4'ü kansere bağlı, 9'u kanser dışı nedenlerden olmak üzere 13'ü kaybedilmiştir. Hastaların izleminde 5'inde larenks, 2'sinde boyun, 3'ünde hem larenks hem boyun olmak üzere toplam $10(\% \quad 13,7)$ olguda lokal-bölgesel nüks saptanmıştır. Medyan lokal nükse kadar geçen süre 4,5 ay olup 2-29 ay aralığında değişmektedir. Nüks gelişen olguların tamamına kurtarma cerrahisi yapılmış, 1'ine kemoterapi (KT) ve ardışık 2. seri RT, 1'ine 2. seri RT ve eşzamanlı KT, 1'ine yalnız 2. seri RT ve 2'sine de yalnız KT uygulanmıştır. Nüks gelişen 10 olgunun 5'i halen yaşarken 4'ü kansere bağlı, 1'i kanser dışı nedenlerden kaybedilmiştir. Olguların hiç birinde uzak metastaz saptanmamıştır. Radyoterapiye bağlı olarak, 1 olguda $(\% 1,4)$ grade 3-4 erken ve geç larengeal ödem gelişmiş, bu olgu dışında diğer olguların hiçbirinde grade 3-4 erken ve geç toksisite ile karşılaşılmamıştır. Bu olgu larengeal nüksün gözlendiği olgulardan biridir.

Hastaların 5 yıllık lokal-bölgesel kontrol, hastalığa özgü sağ kalım ve genel sağ kalım oranları sırası ile \% 85, \% 92 ve \% 78'dir (Şek. 1-3). Lokal-bölgesel kontrol üzerine etkisi 


\section{Tablo 1. Hasta, tümör ve tedavi özellikleri}

Özellik

Hasta sayısı

Yüzde

\section{Cinsiyet}

Erkek

Kadın

Yaş

(medyan $=60 ;$ aralık=83-37)

$<60$

$\geq 60$

Sigara kullanımı

Var

Yok

Bilinmiyor

Alkol kullanımı

Var

Yok

Bilinmiyor

Tedavi öncesi ses kısıklığı süresi (medyan 5 ay; aralık $=60-0,5$ )

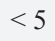

$\geq 5$

Tanıda hemoglobin

(medyan 14,3g/dl; aralık=17,7-9,4)

$<14$

$\geq 14$

T evresi

T1a

$\mathrm{T} 1 \mathrm{~b}$

T2

Ön komissür tutulumu

Var

Yok

Tümör derecesi

Grade 1

Grade 2

Bilinmiyor

RT fraksiyon dozu

$$
200 \text { cGy/gün }
$$

$225 \mathrm{cGy} /$ gün

Toplam RT dozu

$$
\begin{aligned}
& <66 \mathrm{~Gy} \\
& \geq 66 \mathrm{~Gy}
\end{aligned}
$$

Tedavi arası

$$
<5 \text { gün }
$$$$
\geq 5 \text { gün }
$$

Toplam tedavi süresi

(medyan 46 gün; aralık=72-35)

$$
<46
$$$$
\geq 46
$$

Tedavi cihazı

Kobalt 60

Lineer akseleratör
69

4

94,5 araştırılan parametrelerden cinsiyet, yaş, sigara ve alkol kullanımı, tanıda hemoglobin düzeyi, T evresi, ön komissür tutulumu, tümör derecesi, RT fraksiyon dozu, toplam RT dozu, toplam tedavi süresi ve tedavi cihazının lokal-bölgesel kontrol üzerine istatistiksel olarak anlamlı etkisi bulunmazken, tedavi öncesi ses kısıklı̆gı süresi ve RT’ye verilen aranın lokalbölgesel kontrolü anlamlı olarak etkilediği saptandı (Tablo 2). Ses kısıklığının başlangıcından tedaviye başlanıncaya kadar geçen süre 5 ay ve üstünde olanlarda 5 ay altında olanlara göre $(\mathrm{p}=0,036)$ (Şek. 4); RT sürecinde tedaviye 5 günden az ara verilen hastalarda 5 gün ve daha fazla ara verilen hastalara göre $(p=0,008)$ (Şek. 5) lokal-bölgesel kontrol anlamlı olarak daha iyi idi. Hastalığa özgü sağkalım üzerine etkisi araştırılan aynı parametrelerden sadece RT'ye verilen aranın hastalığa özgü sağkalımı istatistiksel olarak anlamlı etkilediği saptandı (Tablo 2). RT'ye 5 günden az ara verilen hastalarda 5 gün ve daha fazla ara verilen hastalara göre hastalığa özgü sağ kalım anlamlı olarak daha iyi bulundu $(\mathrm{p}=0,036)$ (Şek. 6).

\section{Tartışma}

Erken evre glottik yerleşimli larenks kanseri randomize çalışmalar ile doğrulanmış olmamasına rağmen

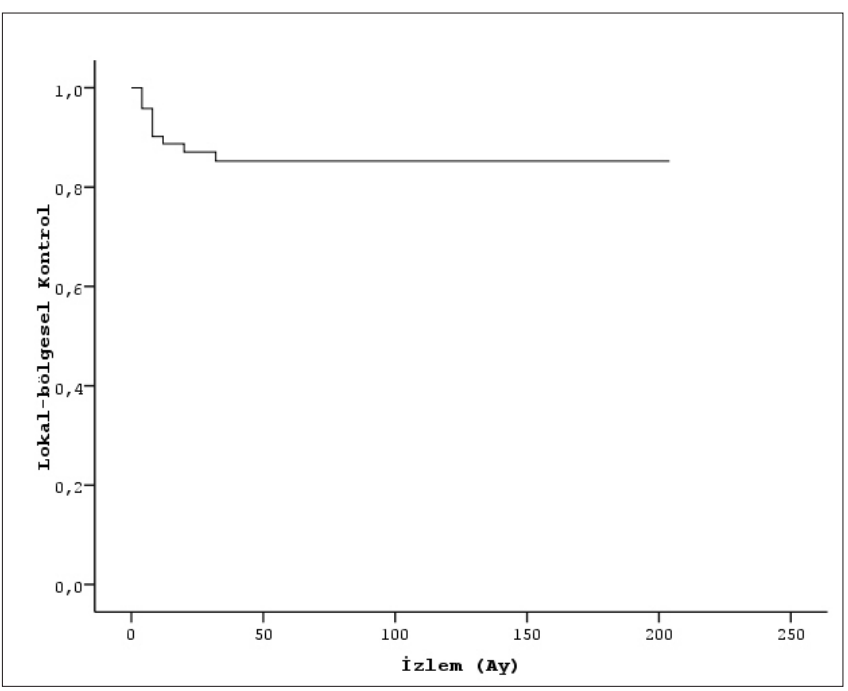

Şek. 1. Lokal-bölgesel kontrol eğrisi

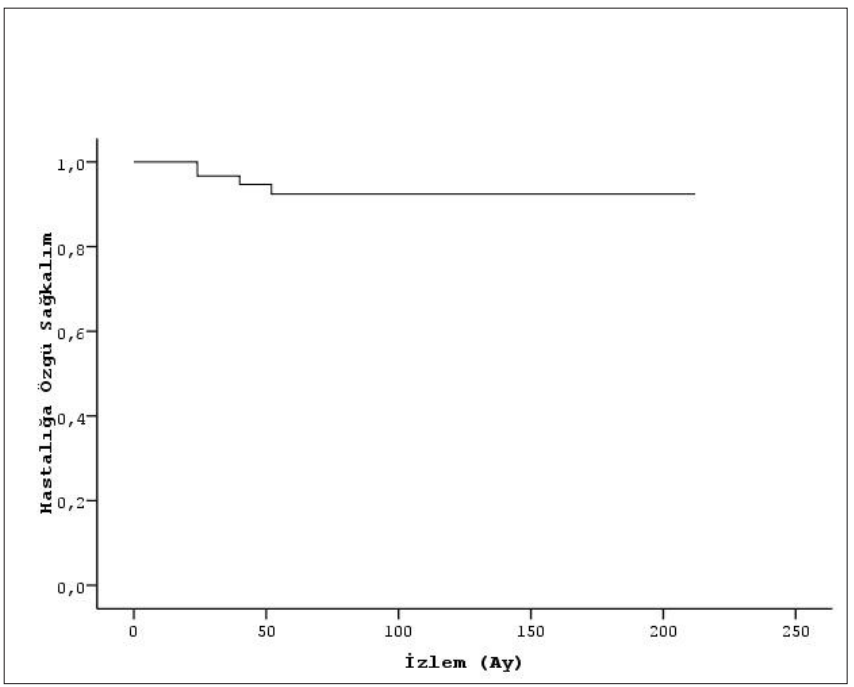

Şek. 2. Hastalığa özgü sağ kalım eğrisi 


\section{Tablo 2. Lokal-bölgesel kontrol ve hastalığa özgü sağ kalıma} etkili faktörler

\begin{tabular}{ccccc}
\hline Özellik & $\begin{array}{c}\text { Beş yıllık } \\
\text { lokal-bölgesel } \\
\text { kontrol } \\
(\%)\end{array}$ & $\boldsymbol{p}$ & $\begin{array}{c}\text { Beş yıllık } \\
\text { hastalığa özgü } \\
\text { sağkalım } \\
(\%)\end{array}$ & $p$ \\
\hline $\begin{array}{c}\text { Cinsiyet } \\
\text { Erkek }\end{array}$ & 86,3 & & 92,3 & \\
$\quad$ Kadın & - & 0,42 & - & 0,72 \\
$\begin{array}{c}\text { Yaş (medyan=60; aralık=83-37) } \\
\quad<60\end{array}$ & & & \\
$\quad 81,1$ & & 91,8 & \\
$\geq 60$ & 89,3 & 0,42 & 93 & 0,92
\end{tabular}

Sigara kullanımı

\begin{tabular}{lllll} 
Var & 84,1 & \multicolumn{3}{c}{90,4} \\
Yok & 87,5 & 0,75 & 100 & 0,38
\end{tabular}

Alkol kullanımı

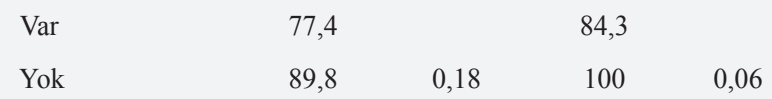

Tedavi öncesi ses kısıklığı süresi (medyan 5 ay; aralık=60-0,5)

$$
\begin{array}{ll}
<5 & 77,6 \\
\geq 5 & 93,2
\end{array}
$$

89,7

95,5

0,31

Tanıda hemoglobin

(medyan 14,3g/dl; aralık=17,7-9,4)
$<14$
83,7
$\geq 14$
86,3

0,97

88,5

94,3

0,55

T evresi

T1

87,5

$\mathrm{T} 2$

79,6

0,60

92,6

90,9

0,87

Ön komissür tutulumu

Var

81,4

Yok

87,9

Tümör derecesi

Grade 1

84

Grade 2

0,42

87,1

0,68

RT fraksiyon dozu

$200 \mathrm{cGy/gün}$

$225 \mathrm{cGy} /$ gün

Toplam RT dozu

$<66 \mathrm{~Gy}$
$\geq 66 \mathrm{~Gy}$

RT arası

$$
<5 \text { gün }
$$$$
\geq 5 \text { gün }
$$

Toplam tedavi süresi (medyan 46 gün; aralık=72-35)

$$
<46
$$$$
\geq 46
$$

0,008

97,1

83,1

0,036

Tedavi cihazı

Kobalt 60

86,3

Lineer akseleratör
83

84,6

86

0,82

88,2

96,2

0,24

95,2

$89,2 \quad 0,08$

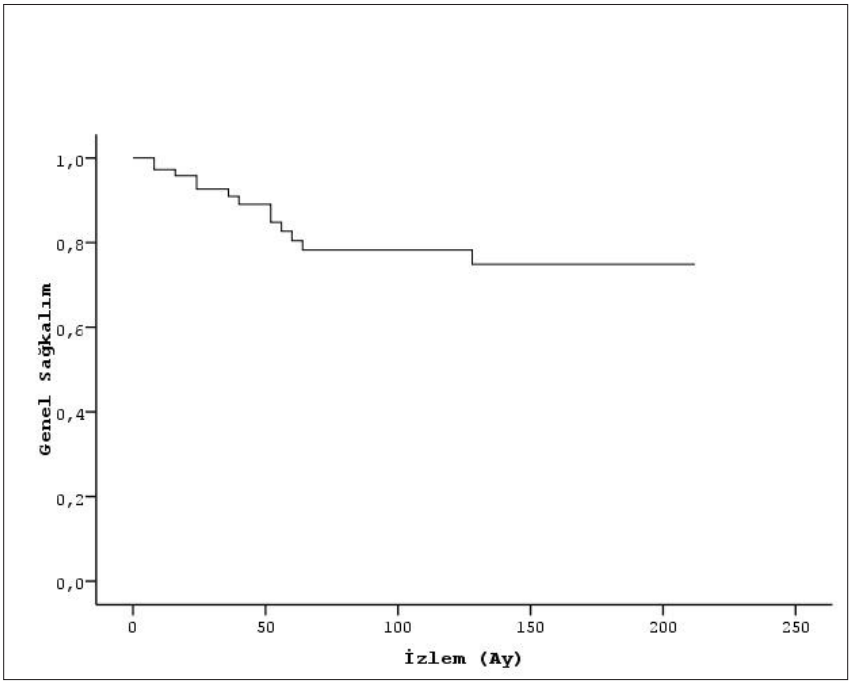

Şek. 3. Genel sağ kalım eğrisi

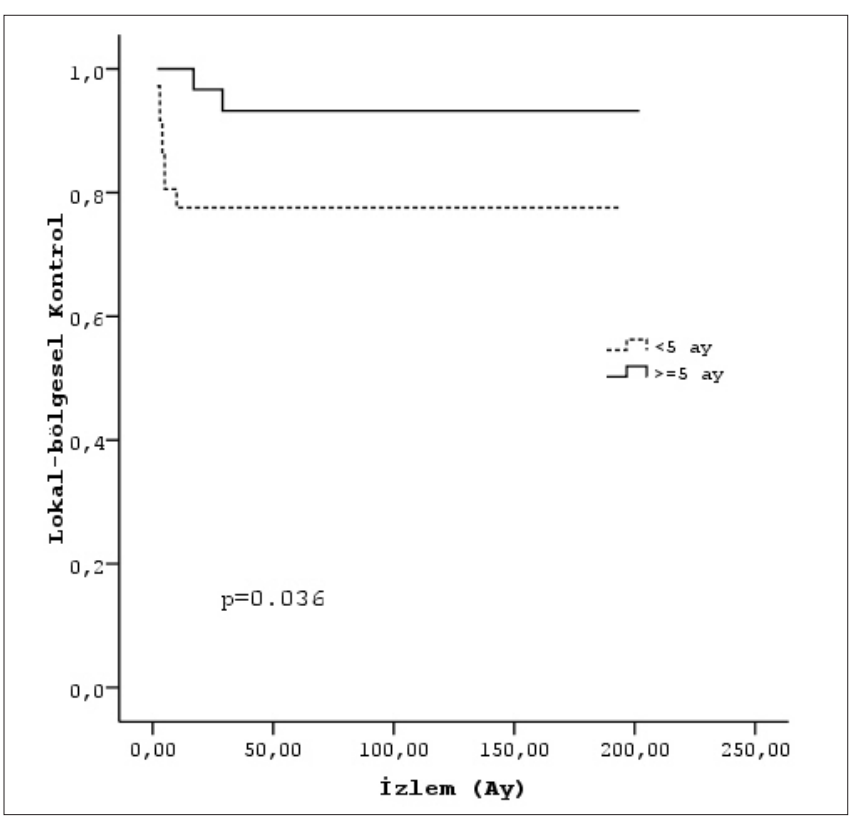

Şek. 4. Tedavi öncesi ses kısıklığı süresinin lokal-bölgesel kontrol üzerine etkisi

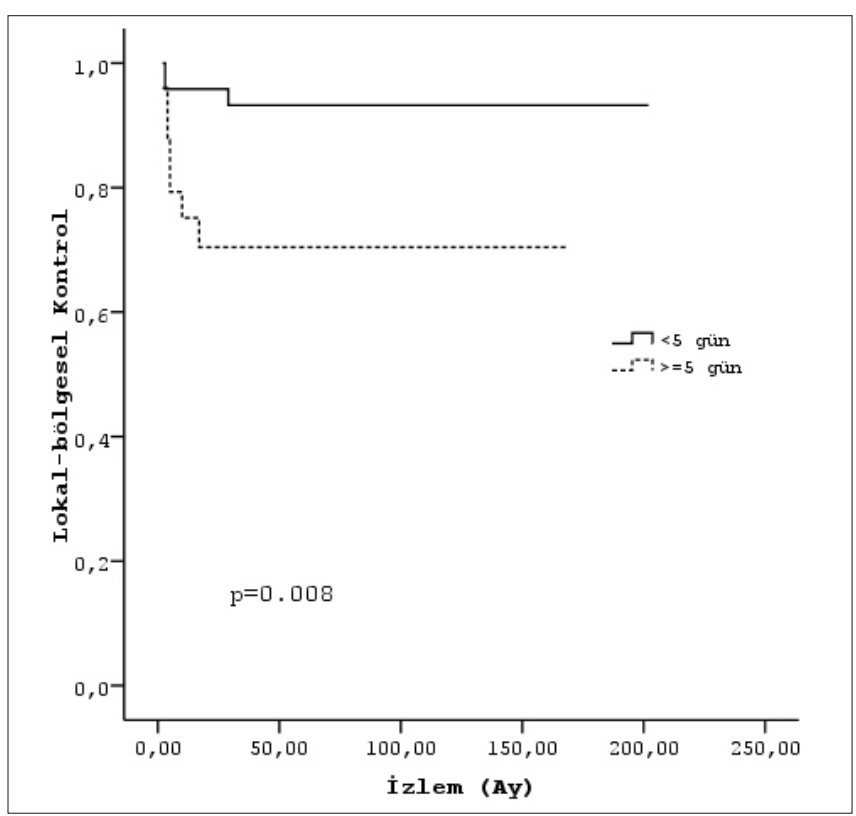

Şek. 5. RT arasının lokal-bölgesel kontrol üzerine etkisi 


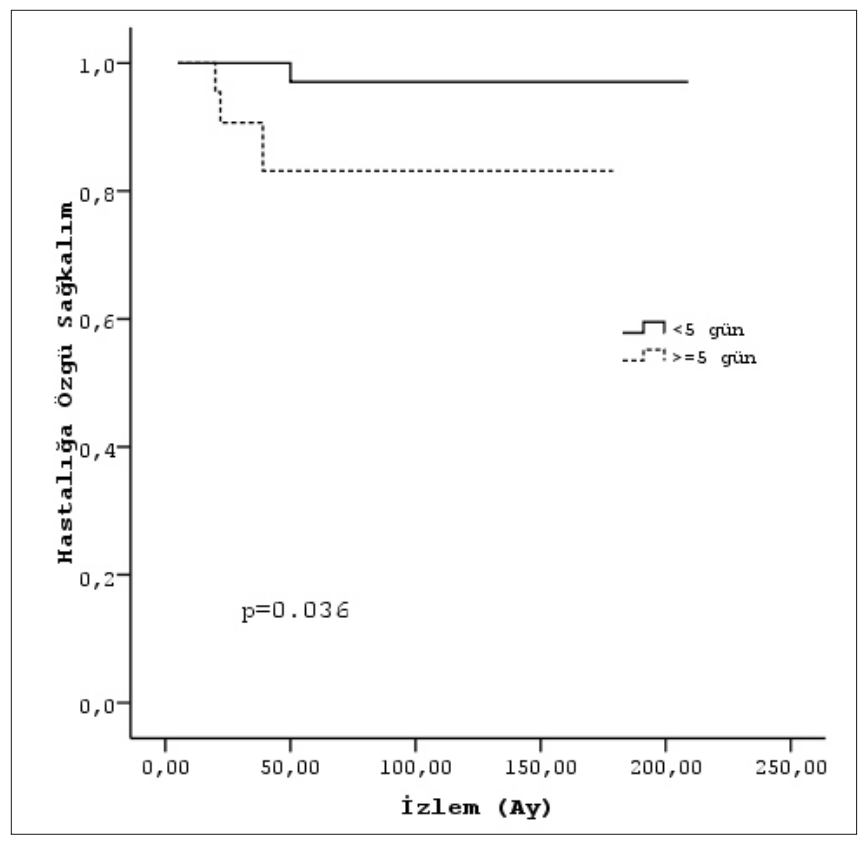

Şek. 6. RT arasının hastalığa özgü sağkalım üzerine etkisi

kordektomi, lazer mikrocerrahi veya parsiyel larenjektomi gibi konservatif cerrahi veya RT ile aynı etkinlikte tedavi edilebilir gözükmektedir (Pelitteri ve ark., 1991; Mendenhall ve ark., 1998). Bununla birlikte genellikle RT ile özellikle daha büyük tümörlerde daha iyi ses kalitesi sağlanmaktadır (Stewart ve ark., 1998; Verdonck-de Leeuw ve ark., 1999). Geriye dönük yapılan çalışma sonuçları bazında genellikle ses korunmasının herhangi bir cerrahi prosedür ile karşılaştırıldığ zaman radyoterapiyi takiben daha iyi olduğu kabul edilmektedir (Fein ve ark., 1993; Mendenhall ve ark., 1994; Tombolini ve ark., 1995). Bu nedenle bir çok merkezde RT tercih edilmekte, cerrahi radyoterapi sonrası nükslere saklanmaktadır (Mendenhall ve ark., 1988; Johansen ve ark., 1990; Le ve ark., 1997; Warde ve ark., 1998; Mendenhall ve ark., 2001).

Erken evre glottik kanserlerin tedavisine ilişkin çok sayıda çalışmada tümör kinetiği (Narayana ve ark., 2000), histolojik diferansiyasyon (Hermans ve ark., 1998), ön komissür tutulumu (Fein ve ark., 1993; Zouhair ve ark., 2004), sigara içimi, tedavi öncesi hemoglobin düzeyi, fraksiyon dozu, toplam doz, toplam tedavi süresi, çevre, yaş, cinsiyet, tedavi sonrası disfoni süresi (Mendenhall ve ark., 1991; Warde ve ark., 1998; Franchin ve ark., 2003; Zouhair ve ark., 2004) gibi çok sayıda faktör değerlendirilmiştir. Ancak bu faktörler her zaman anlamlı prognostik faktörler olarak bildirilmemiştir (Turesson ve ark., 1991; Foote ve ark., 1992; Morris ve ark., 1994).

Tevrelemesi, glottik kanserlerdekieniyibilinenprognostik faktörlerden biridir. Tüm serilerde lokal kontrol oranları T1 tümörlerde T2 tümörlerden daha iyidir. RT sonrası 5 yıllık lokal kontrol oranları T1 tümörler için \% 85-94, T2 tümörler için \% 70-80 aralığında değişmektedir (Mendenhall ve ark., 1988; Le ve ark., 1997; Warde ve ark., 1998; Mendenhall ve ark., 2001). Çalışmamızda da 5 yıllık lokal-bölgesel kontrol oranları T1 tümörler için \% 87,5, T2 tümörler için \% 79,6 olarak bulunmuştur ve bu sonuç daha önce yayınlanmış seriler ile uyumludur. Ancak T1 ve T2 tümörler arasında anlamlı lokal kontrol farkı bulunmamıştır. $\mathrm{Bu}$ sonucun tüm olgular içinde T2 tümör oranının (\% 32,9) nispeten düşük olmasından kaynaklanabileceği düşünülmüştür.

Lokal kontrol oranları toplam doz ve günlük fraksiyon dozu ile de ilişkili bulunmuştur (Kim ve ark., 1992; Spector ve ark., 1999; Mendenhall ve ark., 2001). Günlük 2 Gy ile karşılaştırıldığı zaman günlük 1,8 Gy’lik fraksiyon dozunun anlamlı olarak düşük lokal kontrol oranları sağladığı bildirilmektedir (Kim ve ark., 1992). Bu nedenle birçok merkezde yaygın olarak kullanılan doz-fraksiyonasyon şeması 2 Gy fraksiyonlarla verilen T1 tümörler için 66 Gy, T2 tümörler için 70 Gy'dir. Geriye dönük yapılan çalışmalarda (Le ve ark., 1997; Franchin ve ark., 2003) 225 cGy ve üstü fraksiyon dozu ile daha iyi lokal kontrol oranları sağlandığ bildirilirken; yayınlanan prospektif bir çalışmada (Yamazaki ve ark., 2006) T1N0 skuamöz hücreli glottik larenks kanserinde fraksiyon başına 2,25 Gy ile 2 Gy karşılaştırılmış, erken ve geç toksisitede fark olmaksızın 5 yıllık lokal kontrol oranları 2,25 Gy kolunda anlamlı olarak yüksek bulunmuştur. Çalışmamızda da hastaların \% 41,1'i 2,25 Gy fraksiyon dozu ile ışınlanmış, ancak 2 Gy ile ışınlanan grup ile arasında anlamlı fark bulunmamıştır. Bu durumun 2,25 Gy'lık gruptaki hasta sayısının nispeten düşük olması ve bu grubun izlem süresinin daha kısa olmasından kaynaklanabileceği düşünülmüştür.

Glottik kanserlerin çoğunluğu vokal kordların ön kısmında ortaya çıkmakta ve oldukça sık ön komissürü tutmaktadır (Zouhair ve ark., 2004). Anatomik olarak potansiyel bir tümör bariyeri olarak görev yapacak olan ön komissür perikondrial bir ayırım olmaksızın direkt tiroid kartilaja tutunmaktadır (Zouhair ve ark., 2004). Bu bölge tümör yayılımı için göreceli olarak zayıf bir alan oluşturmaktadır (Shvero ve ark., 1994). Bu nedenle lokal kontrolün ön komissür tutulumu olan hastalarda daha kötü olması beklenmektedir. Ancak yayınların bir kısmında ön komissür tutulumunun lokal kontrolü azaltan bir faktör olduğu bildirilirken (Shvero ve ark., 1994; Hirota ve ark., 1996) diğerlerinde olmadığ (Benninger ve ark., 1994; Mendenhall ve ark., 2001). Bir çalışmada ön komissür tutulumunun çok değişkenli analizde lokal kontrolü etkileyen bağımsız prognostik bir faktör olduğu bulunmuştur (Zouhair ve ark., 2004). Çalışmamızda ön komissür tutulumu olan olgularda lokal-bölgesel ve hastalıksız sağkalım oranlarının daha düşük olmasına rağmen anlamlı bir prognostik faktör olmadığı saptanmıştır.

Tedavi süresi fraksiyon boyutuna, klinik şartlarına (tedavi cihazı arıası gibi), toksisite nedeniyle tedaviye ara verilmesine ve hastanın sosyo-kültürel, ekonomik şartlarına (hastanın sosyal veya ekonomik nedenlerden dolayı düzenli olarak tedaviye gelememesi gibi) göre değişebilmektedir. Toplam tedavi süresinin çeşitli baş-boyun kanserlerinde RT sonrası lokal kontrol ile anlamlı olarak ilişkili olduğu gösterilmiştir (Mendenhall ve ark., 2001). Baş-boyun kanserlerinde radikal radyoterapi klinik sonuçlarını bildiren 12 çalışmanın metaanalizinde tedavi süresinde 1 haftalık bir uzamanın medyan \% 14 (\% 3-35), iki haftalık bir uzamanın ise \% 26 (5-42) oranında lokal kontrol kaybına neden olduğu bildirilmiştir (Fowler ve Lindstrom, 1992). RT süresince tümör repopülasyonunu azaltmak için akselere fraksiyonasyon veya hipofraksiyonasyon ile toplam tedavi süresinin kısaltılmasının konvansiyonel fraksiyonasyona üstün olduğu gösterilmiştir (Mendenhall ve ark., 2000; Yamazaki ve ark., 2006). Çalışmamızda toplam tedavi süresinin lokal-bölgesel kontrol ve hastalığa özgü sağkalıma 
anlamlı etkisi saptanmazken tedaviye 5 gün veya daha fazla ara verilmesinin hem lokal-bölgesel kontrolü hem de hastalığa özgü sağkalımı anlamlı olarak azalttığı bulunmuştur. Bu sonuç RT fraksiyon dozundan çok tedavi araları nedeniyle toplam tedavi süresindeki uzamanın tedavi başarısını azalttığını düşündürmüştür. Yapılan bir diğer çalışmada RT'ye 5 günden fazla ara verilmesinin, bizim sonucumuzla uyumlu olarak, lokal bölgesel kontrolü etkileyen prognostik bir faktör olduğu bildirilmiştir (Esassolak ve ark., 2006).

Ses kısıklığı larenks kanserlerinde en sık görülen semptom olmasına karşın en çok glottik kanserlerde görülmektedir. Küçük vokal kord tümörlerinde bile görülebilmekte, erken tanı ve tedavi sonuçlarının iyileşmesine katkı sağlayabilmektedir (Raitiola ve Pukander, 2000). Bizim olgularımızda lokalbölgesel kontrol tedavi öncesi ses kısıklığı süresi 5 ay altında olanlarda, 5 ay ve üstünde olanlara göre anlamlı olarak daha düşük bulunmuştur. Bu sonuç başka araştırmacıların sonuçları ile çelişkili görünmekte ve net olarak da açıklanamamıştır. Ancak tümörlerin intrinsik agresifliği değişmektedir (Vernham ve Crowther, 1994). Hızlı büyüyen tümörlerin neden olduğu semptom paterni daha az agresif lezyonlardan farklı olabilmektedir (Merletti ve ark., 1990). Bu nedenle daha agresif tümörü olan hastaların ses kısıklığındaki hızlı değişimin hastaları daha erken dönemde doktora yönlendirmiş olabileceği ancak tümörün agresif paterni nedeni ile lokal kontrolün azalmış olabileceği düşünülmektedir.

Definitif RT uygulanan erken evre glottik larenks kanserlerinin lokal kontrol oranlarında büyük bir varyasyon bulunmaktadır. $\mathrm{Bu}$ varyasyon aynı evrede tümörü olan hastalarda da mevcuttur. Bir çok çalışmada erken evre glottik kanserlerde hastaya, tümöre ve tedaviye ait faktörlerin, yayınlanan serilerde de sonuçlar değişmekle birlikte, lokal kontrolü etkileyeceği bulunmuştur. Ancak bu faktörler definitif radyoterapi uygulanan aynı evredeki farklı tümör davranışını açıklamak için yeterli olmayabilir. Çalışmamızdaki lokal kontrol ve sağ kalım oranları yayınlamış serilerde verilen oranlara benzer olmasına rağmen, lokal kontrol ve sağ kalımı etkileyebileceği düşünülen benzer parametreler araştırılmış ancak bu faktörlerden sadece tedavi arasının ve tedavi öncesi ses kısıklığı süresinin lokal kontrol ve hastalıksız sağ kalıma etkisi saptanmıştır. Bu sonucun, çalışmamızdaki hasta sayısının nispeten düşük olmasından kaynaklandığ 1 düşünülebilir. Ancak diğer serilerde de farklı çalışmalarda farklı sonuçların elde edilmesi ek bazı moleküler faktörlerin (Demiral ve ark., 2004; Korkmaz ve ark., 2005; Sackett ve ark., 2008) de lokal kontrol ve sağ kalımda etkili olabileceğini düşündürmektedir.

RT genel olarak iyi tolere edilmektedir ve bildirilen ciddi komplikasyon oranları düşüktür (Franchin ve ark., 2003; Zouhair ve ark., 2004). Bizim çalışmamızda da sadece 1 olguda (\%1.4) grade 3-4 toksisite karşılaşılmışıtır. Larengeal nüksün de gözlendiği bu olgunun tedavi sırasında sigara içmeye devam etmesinin, lokal kontrolün sağlanamamasında ve komplikasyon gelişmesinde etkili olduğu düşünülmektedir."

Sonuçlarımız erken evre glottik larenks kanserinde RT ile elde edilen yüksek tedavi oranlarını doğrulamaktadır. $\mathrm{Bu}$ grup olgularda primer tedavi olarak radyoterapi yüksek lokal kontrol oranlarına sahip etkin bir tedavi şeklidir. Ancak RT'ye çeşitli nedenlerden dolayı verilen ara lokal-bölgesel kontrol ve hastalıksız sağkalımı olumsuz etkileyen prognostik bir faktördür. $\mathrm{Bu}$ nedenle tedavi aralarından mümkün olduğunca kaçınılmalı, tedavi plana uygun olarak bir an önce sonlandırılmalıdır.

\section{KAYNAKLAR}

Benninger, M.S., Gillen, J., Thieme, P., Jacobson, B., Dragovich, J., 1994. Factors associated with recurrence and voice quality following radiation therapy for T1 and T2 glottic carcinomas. Laryngoscope. 104, 294-298.

Demiral, A.N., Sarioglu, S., Birlik, B., Sen, M., Kinay, M., 2004. Pronostic significance of EGF receptor expression in early glottic cancer. Auris Nasus Larynx. 31, 417-424.

Esassolak, M., Dubova, S., Kamer, S., Aydın, B., 2006. Erken evre glottik larenks kanserlerinde küratif radyoterapi. Türk Onkoloji Dergisi. 21, 28-36.

Fein, D.A., Mendenhall, W.M., Parsons, J.T., Million, R.R., 1993. T1-T2 squamous carcinoma of glottic larynx treated with radiotherapy: a multivariate analysis of variables potentially influencing local control. Int. J. Radiat. Oncol. Biol. Phys. 25, 605-611.

Foote, R.L., Olsen, K.D., Kunselman, S.J., Schaid, D.J., Buskirk, S.J., Grado, G.L., Earle, J.D., 1992. Early-stage squamous cell carcinoma of the glottic larynx managed with radiation therapy. Mayo Clin. Proc. 67, 629-636.

Fowler, J.F., Lindstrom, M.J., 1992. Loss of local control with prolongation in radiotherapy. Int. J. Radiat. Oncol. Biol. Phys. 23, 457-467.

Franchin, G., Minatel, E., Gobitti, C., Talamini, R., Vaccher, E., Sartor, G., Politi, D., Trovo, M.G., Barzan, L., 2003. Radiotharapy for patients with early-stage glottic carcinoma: Univariate and multivariate analyses in a group of consecutive, unselected patients. Cancer. 98, 765772.

Hermans, R., Feron, M., Bellon, E., Dupont, P., Van den Bogaert, W., Baert, A.L., 1998. Laryngeal tumor volume mesurement determined with CT: A study on intra-and interobserver variability. Int. J. Radiat. Oncol. Biol. Phys. 40, 553-557.

Hirota, S., Soejima, T., Obayashi, K., Hishikawa, Y., Honda, K., Okamoto, Y., Maeda, H., Takada, Y., Inoue, K., Kinishi, M., Amatsu, M., Kimura, S., 1996. Radiotherapy of T1 and T2 glottic cancer: Analysis of anterior commissure involvement. Radiat. Med. 4, $297-302$.

Johansen, L.V., Overgaard, J., Hjelm-Hansen, M., Gadeber, C.C., 1990. Primary radiotherapy of T1 squamous cell carcinoma of the larynx: analysis of 478 patient treated from 1963 to 1985. Int. J. Radiat. Oncol. Biol. Phys. 18, 1307-1313.

Kim, R.Y., Marks, M.E., Salter, M.M., 1992. Early-stage glottic cancer: Importance of dose fractionation in radiation therapy. Radiology. 182, 273-275.

Korkmaz, H., Du, W., Yoo, G.H., Enamorado, I.I., Lin, H.S., Adsay, V., Kewson, D., Ensley, J.F., Shibuya, T.Y., Jacobs, J.R., Kim, H., 2005. Prognostic significance of G1 cell-cycle inhibitors in early laryngeal cancer. Am. J. Otolaryngol. 26, 77-82.

Le, Q.T., Fu, K.K., Kroll, S., Ryu, J.K., Quivey, J.M., Meyler, T.S., Krieg, R.M., Phillips, T.L., 1997. Influence of fraction size, total dose and overall time on local control of T1-T2 glottic carcinoma. Int. J. Radiat. Oncol. Biol. Phys. 39, 115-126.

Mendenhall, W.M., Amdur, R.J., Morris, C.G., Hinerman, R.W., 2001. T1-T2N0 squamous cell carcinoma of the glottic larynx treated with radiation therapy. J. Clin. Oncol. 19, 4029-4036.

Mendenhall, W.M., Amdur, R.J., Siemann, D.W., Parsons, J.T., 2000. Altered fractionation in definitive irradiation of squamous cell carcinoma 
of the head and neck. Curr. Opin. Oncol. 12, 207-214.

Mendenhall, W.M., Parsons, J.T., Million, R.R., Fletcher, G.H., 1988. T1-T2 squamous cell carcinoma of the glottic larynx treated with radiation therapy: Relationship of dose fractionation factors to local control and complications. Int. J. Radiat. Oncol. Biol. Phys. 15, 1267-1273.

Mendenhall, W.M., Parsons, J.T., Stringer, S.P., Cassisi, N.J., 1994. Management of Tis, T1, T2 squamous cell carcinoma of the glottic larynx. Am. J. Otolaryngol. 15, 250-257.

Mendenhall, W.M., Parsons, J.T., Stringer, S.P., Cassisi, N.J., Million, R.R., 1988. T1-T2 vocal cord carcinoma: A basis for comparing the result of radiotherapy and surgery. Head Neck. 10, 373-377.

Merletti, F., Faggiano, F., Boffetta, P., Lehmann, W., Rombola, A., Amasio, E., Tabaro, G., Giordano, C., Terracini, B., 1990. Topographic classification, clinical characteristics, and diagnostic delay of cancer of the larynx/hypopharynx in Torino, Italy. Cancer. 66, $1711-1716$.

Morris, M.R., Canonico, D., Blank, C., 1994. A critical review of radiotherapy in the management of T1 glottic carcinoma. Am. J. Otolaryngol. $14,276-280$.

Narayana, A., Vaughan, A.T., Kathuria, S., Fisher, S.G., Walter, S.A., Reddy, S.P., 2000. P53 overexpression is associated with bulky tumor and poor local control in T1 glottic cancer. Int. J. Radiat. Oncol. Biol. Phys. 46, 21-26.

Pelitteri, P.K., Kennedy, T.L., Vrabec, D.P., Beiler, D., Hellstrom, M., 1991. Radiotherapy: The mainstay in the treatment of early glottic carcinoma. Arch. Otolaryngol. Head Neck Surg. 117, 297-302.

Raitiola, H., Pukander, J., 2000. Symptoms of laryngeal carcinoma and their prognostic significance. Acta. Oncol. 39, $213-216$.

Rudoltz, M.S., Benammar, A., Mohiuddin, M., 1993. Prognostic factors for local control and survival in T1 squamous cell carcinoma of the glottis. Int. J. Radiat. Oncol. Biol. Phys. 26, 767-772.

Sackett, M.K., Bairati, I., Meyer, F., Jobin, E., Lussier, S., Fortin, A., Gelinas, M., Nabid, A., Brochet, F., Tetu, B., 2008. Prognostic significance of cyclooxygenase-2 overexpression in glottic cancer. Clin. Cancer Res. 14, 67-73.

Shvero, J., Hadar, T., Segal, K., Yaniv, E., Marshak, G., Feinmesser, R., 1994. T1 glottic carcinoma involving the anterior commissure. Eur. J. Surg. Oncol. 20, 557-560.

Spector, J.G., Sessions, D.G., Chao, K.S., Haughey, B.H., Hanson, J.M., Simpson, J.R., Perez, C.A., 1999. Stage I (T1 N0 M0) squamous cell carcinoma of the laryngeal glottis: therapeutic results and voice preservation. Head Neck. 21, 707-717.

Stevenson, J.M., Juillard, G.J., Selch, M.T., 1992. Stages 1 and 2 epidermoid carcinoma of the glottic larynx: Involment of anterior comissure. Radiology. 182, 797-799.

Stewart, M.G., Chen, A.Y., Stach, C.B., 1998. Outcome analysis of voice and quality of life in patient with larengeal cancer. Arch. Otolaryngol. Head Neck Surg. 124, 143-198.

Tombolini, V., Zurlo, A., Cavaceppi, P., Sarro, A., Guidi, C., Osti, M.F., Vitturini, A., Banelli, E., 1995. Radiotherapy for T1 carcinoma of the glottis. Tumori. 81, 414-418.

Turesson, I., Sandberg, N., Mercke, C., Johansson, K.A., Sandin, I., Wallgren, A., 1991. Primary radiotherapy of glottic laryngeal carcinoma stage I and II. A retrospective study with special regard to failure patterns. Acta Oncol. 30, 352-362.

Verdonck-de Leeuw, I.M., Hilgers, F.J., Keus, R.B., Koopmans-van Beinum, F.J., Greven, A.J., de Jong, J.M., Vreeburg, G., Bartelink, H., 1999. Multidimensional assesment of voice characteristics after radiotherapy for early glottic cancer. Laryngoscope. 109, 241-248.

Vernham, G.A., Crowther, J.A., 1994. Head and neck carcinoma-stage at presentation. Clin. Otolaryngol. Allied. Sci. 19, 120-124.

Warde, P., O’Sullivan, B., Bristow, R.G., Panzarella, T., Keane, T.J., Gullane, P.J., Witterick, I.P., Payne, D., Liu, F.F., McLean, M., Waldron, J., Cummings, B.J., 1998. T1-T2 glottic cancer managed by external beam radiotherapy: Influence of pretreatment hemoglobin on local control. Int. J. Radiat. Oncol. Biol. Phys. 41, 347-353.

Yamazaki, H., Nishiyama, K., Tanaka, E., Koizumi, M., Chatani, M., 2006. Radiotherapy for early glottic carcinoma (T1N0M0): Results of prospective randomized study of radiation fraction size and overall treatment time. Int. J. Radiat. Oncol. Biol. Phys. 64, 77-82.

Zouhair, A., Azria, D., Coucke, P., Matzinger, O., Bron, L., Moeckli, R., Do, H.P., Mirimanoff, R.O., Ozsahin, M., 2004. Decreased local control following radiation therapy alone in early-stage glottic carcinoma with anterior comissure extension. Strahlenther. Onkol. 180, 84-90. 